\title{
Generation of young scientists in peril
}

Sir-As a former scientist married to someone who is in his second year of a postdoctoral fellowship, I could not agree more with John Moore's comments on the sad state of funding for young scientists in the United States (Nature 395, 431; 1998). I suspect that the career situation for scientists will get worse before it gets better, resulting in the frustration and demoralization of a generation of bright young people. I hope that the voices of people such as Moore will be heard in Congress before the next generation of scientists is lost.

My decision to leave my postdoc was based on several factors, but one of the primary reasons was concern that we would not be able to support a family on two postdoc salaries. Most of my colleagues believed that I would be able to succeed in academic research, but they all supported my decision then and agree now that it was the right move. Although my husband is committed to research, we sometimes wonder about our financial future.

I now work at a public relations firm that specializes in the biotechnology, pharmaceutical and healthcare sectors. In addition to providing better wages and benefits, this position offers something that is sorely lacking in academia: recognition and reward for a job done well. I have twice been promoted, and get daily positive reinforcement from co-workers and clients.

My office recently hired a friend of mine from graduate school, my sister left science for a job on Wall Street and another friend is thinking of leaving her postdoc for a job in industry where she could earn more and have more time to spend with her child. Judging from the résumés I receive each month from scientists seeking new job opportunities, we are not alone.

Without changes to the current system, I fear that financial realities will force a growing number of talented people to seek alternative careers that will enable them to use their hard-earned degrees for greater monetary reward.

Stephanie Seiler

Noonan/Russo Communications, 220 Fifth Avenue, New York 10001, USA

Sir - John Moore rightly suggests that one way to attract bright US students to postdoctoral positions, and eventually to academia, is to raise their salaries. But his concluding sentence appears to suggest the wrong solution.

If the government spends money to "train more young scientists" this should tend to create a further glut of postdocs, and depress their salaries further. To raise salaries, we should be funding fewer young scientists in order to pay them individually more with the same pot of money.

Keith Alverson

Past Global Changes International Project Office, Bern, Switzerland

\section{Wronged by Crookes}

Sir - The 10 September Daedalus column was, as usual, fascinating and charming (Nature 395, 120; 1998). But it raises the possibility of a grave academic injustice dating from nearly 20 years ago.

At the time, I was a sophomore in a prestigious university in the American Midwest (we'll leave out the institution's name, but its initials are University of Chicago). I recall with chagrin breaking up on the rocks of an introductory quantum mechanics examination (I had an A grade going into the final) in which one of the questions was an explanation of the Crookes radiometer, as dealt with by Daedalus.

Never mind what I answered; you're not going to get me to admit to that. But the correct answer, I was told by a tired-looking professor, was that photons hitting the black side of the vane were experiencing an inelastic collision, while those hitting the white side were colliding elastically. The inelastic collision imparted a momentum, $P$ (derived from the photon), onto the vane, but in order to conserve momentum the elastic one had to impart a $2 P$ momentum. Hence, motion in the direction of the black side of the vanes, QED.

I existed at the time in a perpetual state of indignation, which was not helped by the intrusion of classical mechanics into my world of hamiltonian operators and eigenfunctions (any misuse of terms, by the way, I blame on my teachers).

Now, however, Daedalus provides a mechanism of action for the Crookes radiometer that deviates from the given wisdom of that fateful day, nigh on two decades ago. Have I been wronged? Should I bring this case before the university's ethics committee? I am, of course, willing to dispense with any considerations of academic collegiality or respect for a talented researcher/teacher. I'm a journalist now, I need neither.

I await a reply with high expectations of twisting that A out of said professor. Better late than never.

\section{Kenneth B. Chiacchia}

Public Relations, UPMC Health System, 200 Lothrop Street, Pittsburgh, Pennsylvania 15213, USA

\section{On the world stage}

Sir - Your article "Urgent thinking required about development" refers to the World Conference on Science to be organized next year in Budapest by the United Nations Educational, Scientific and Cultural Organization (Nature 395, 527; 1998). In fact this conference is jointly sponsored by UNESCO and the International Council for Science (ICSU).

This is the first time that UNESCO, a governmental organization, has joined with a non-governmental organization to cosponsor such an international event.

The conference will be held from 26 June to 1 July, not in May as stated in your article, and will deal with such topics as sustainable development, science and development, science and industry, and knowledge as a public good.

Jean-François Stuyck-Taillandier

(Executive director)

ICSU, 51 Bld de Montmorency, 75016 Paris, France

\section{Fishing for compliments}

Sir - There is an alternative explanation for the cause of citation errors to that offered by Nicholas Price (Nature 395, 538; 1998).

In 1957, I was the author, with R. J. H. Beverton, of a book (On the Dynamics of Exploited Fish Populations, HMSO) which, according to citation indexes, is still the most cited reference in fisheries science. We both occasionally wondered why that should be when the book was long out of print — until republished in 1993 — and not readily available outside specialized libraries. It seemed that it became 'politically correct' for newcomers to our field to cite our work, and a considerable proportion of them had clearly never read or even seen it, as we could tell from internal evidence in their publications.

So one or two incorrect references reproduced themselves; they were not mistakes or typos or due to simple carelessness. Naturally, we were proud of our citation records, but, as we say here, it is un po' esagerata.

Sidney Holt

Podere il Falco, 06060 Ponticelli PG, Italy 